\title{
Lege, læge, lækjar, läkare, lekjaz osv.
}

\author{
Skriftspråkene endres stadig slik at de i rimelig grad er i samsvar \\ med det levende, muntlige dagligspråket. Et eksempel på dette er \\ skiftet fra Lægeforeningen til Legeforeningen i 2007. Jeg vil her gi \\ noen eksempler på hvordan trekk ved språkenes utvikling kan kaste \\ lys over medisinsk nomenklatur. Inspirert av årets Darwin-jubileum \\ vil jeg også kort peke på noen påfallende likheter mellom biologisk \\ og språklig utvikling slik man forstår disse i dag.
}

Homo sapiens utvandret fra Afrika for 50 000-100 000 år siden, kanskje før Tobavulkanutbruddet for ca. 75000 år siden $(1,2)$. Individene som forlot Afrika, muligens for 85000 år siden, dro trolig over det trange sundet som forbinder Rødehavet med Indiahavet. Denne gruppen var sannsynligvis meget liten, kanskje ikke flere enn $100-1000$ individer $(1,2)$. De kan ha hatt et felles språk, men når språk egentlig utviklet seg, er ukjent. Et mulig urspråk, forløperen for alle språkfamiler, har vært postulert og foreslått kalt nostratisk (3). Senere utviklet mange ulike språkfamiler seg, særlig på de amerikanske kontinentene (1), mens den indoeuropeiske språkfamilien etter hvert helt har dominert i Europa.

\section{Indoeuropeiske språk}

Sir William Jones (1745-94) var en engelsk jurist som selvsagt hadde lært gresk og latin før han begynte som dommer i Calcutta. Etter å ha fått innsikt i sanskrit, uttalte han: «No philologer can examine Sanskrit, Greek and Latin, without believing them to have sprung from the same common source, which perhaps, no longer exists.» Dette har vist seg riktig (4-6). Om man undersøker ord og struktur i språk innen den indoeuropeiske språkfamilien, finner man at språkene er i slekt (4-6). Den har hatt utbredelse fra tokarisk i Det fjerne østen til keltiske språk vest i Europa, og dominerer i Europa og andre steder på grunn av kolonialismen. Siden Jones' oppdagelse har språkforskere undersøkt slektskapet mellom de enkelte språk i denne familien, også for senere oppdagede språk. Man mener at språkene har utviklet seg fra et prehistorisk, og derfor ekstrapolert, felles grunnspråk som kalles protoindoeuropeisk. Man kan som illustrasjon på denne utviklingen tegne språktrær der språk som er nær beslektet, er gruppert sammen. Slike språktrær blir fort kompliserte om de både skal uttykke slektskap og tidsforløp. Det finnes flere gode eksempler i litteraturen $(4,5,7)$. Språkendringene har en viss hastighet og følger bestemte, forutsigbare endringer over tid, selv om ulike meninger kan finnes i ulike kilder (4-6). Et språktre kan minne mye om et dendrogram over biologiske arter (8).

\section{Språkutvikling}

Språk er stadig under utvikling. Om skriftspråket ikke endres i samsvar med utviklingen av det talte språket, vil avstanden mellom det språket som brukes av befolkningen, og skriftspråket bli så stor at det skaper betydelige problemer. Situasjonen i Irland rundt år 1900 er illustrerende.

Gammelirsk ble skrevet ned midt på 1300tallet, men ble ikke oppdatert før omkring år 1900. På den tiden kunne derfor bare rundt 100 individer irsk-keltisk - de fleste av dem var geistlige. Skriftspråket mistet derved sin normerende effekt, og muntlig kommunikasjon mellom befolkningsgrupper led så mye at selv folk fra naboøyer ikke forsto hverandre. På denne bakgrunnen ble så irsk modernisert. Oppsiktsvekkende nok var den første redaktøren av den nye nasjonale irske ordboken nordmannen Carl Marstrander (1883-1965) (9). Det er altså viktig å modernisere språk etter hva som faktisk er dagens språkbruk. De fleste av oss har vel et greiere forhold til «lege» enn til «læge», hvilket fremgår av de fleste resepter jeg har sett de siste tiårene.

\section{Eksempler på protoindoeuropeiske røtter}

Vi har lært at mange medisinske uttrykk har utspring i latin og gresk. Men ofte har språkvitere funnet enda dypere røtter (4-6, $8,10)$. Ved å undersøke særlig de eldste skrevne og de minst endrede indoeuropeiske språkene som hettittisk, mykensk gresk, sanskrit og det forbausende velbevarte litauisk $(4,6,10)$, og ved ekstrapolering og viten om lydendringer over tid, har man greid å komme frem til vel 2000 sannsynlige protoindoeuropeiske grunnstammer til ord. Ofte dekker de i utgangspunktet begreper for konkrete, menneske- nære, dagligdagse forhold, og ting. Men de har over tid i tillegg utviklet mange til dels overraskende, mer abstrakte avledninger. Nedenfor gir jeg enkelte eksempler:

Watar er det protoindoeuropiske ordet for vann. Dette er så utgangspunkt for ord for $\mathrm{H}_{2} \mathrm{O}$ i mange språk. Vinter: den våte årstid. Oter kommer fra samme rot via wotter; vanndyret. Voda, slavisk vann, er blitt til lillevann: vodka (4-6). Uten denne roten og dens forgreninger i tid og rom kunne ikke F. Stabel ha formulert: «Det er vondt når vetet vanter - men det er vondare å vanta votter om vetteren.»

Angina har den protoindoeuropeiske rot angh: å klemme sammen. Særlig kjent for oss med tilnavnet pectoris og streptokokkal og difteritisk angina tonsillaris. Det sies at mange ord som opprinnelig betydde handlinger, etter hvert er overført til å bety følelser. Avledning: angst, anger (4-6). I engere kretser: jf. noen har snakket sammen.

Lege har den protoindoeuropeiske roten leg (å samle - med avledningen å tale). Laece finner man i gammelengelsk og lekjaz i gammelgermansk. Det siste betydde en fortroller: en som taler magiske ord. Dette må ha vært ren placebo. Etter at blodigler (11) (med over 600 arter, selv om

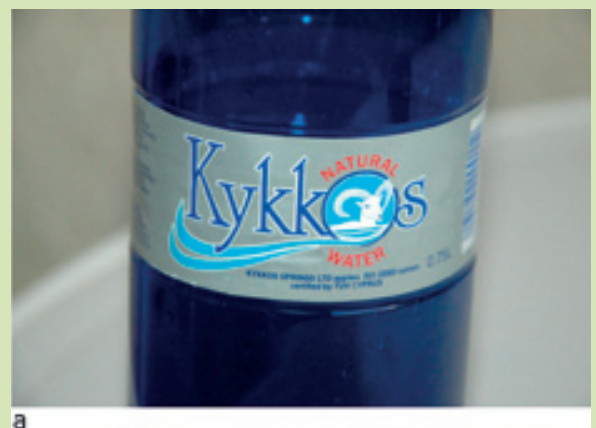

a

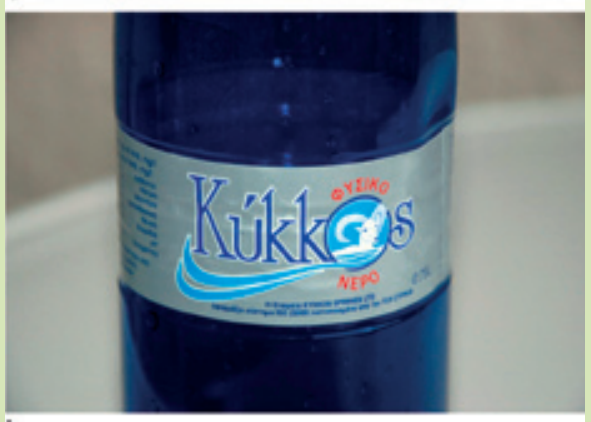

b

Figur 1 Denne greske mineralvannflasken har en etikett på hver side av flasken med al engelsk og b) gresk tekst: Natural water og Fysiko nero. Alle foto E. Arne Høiby 


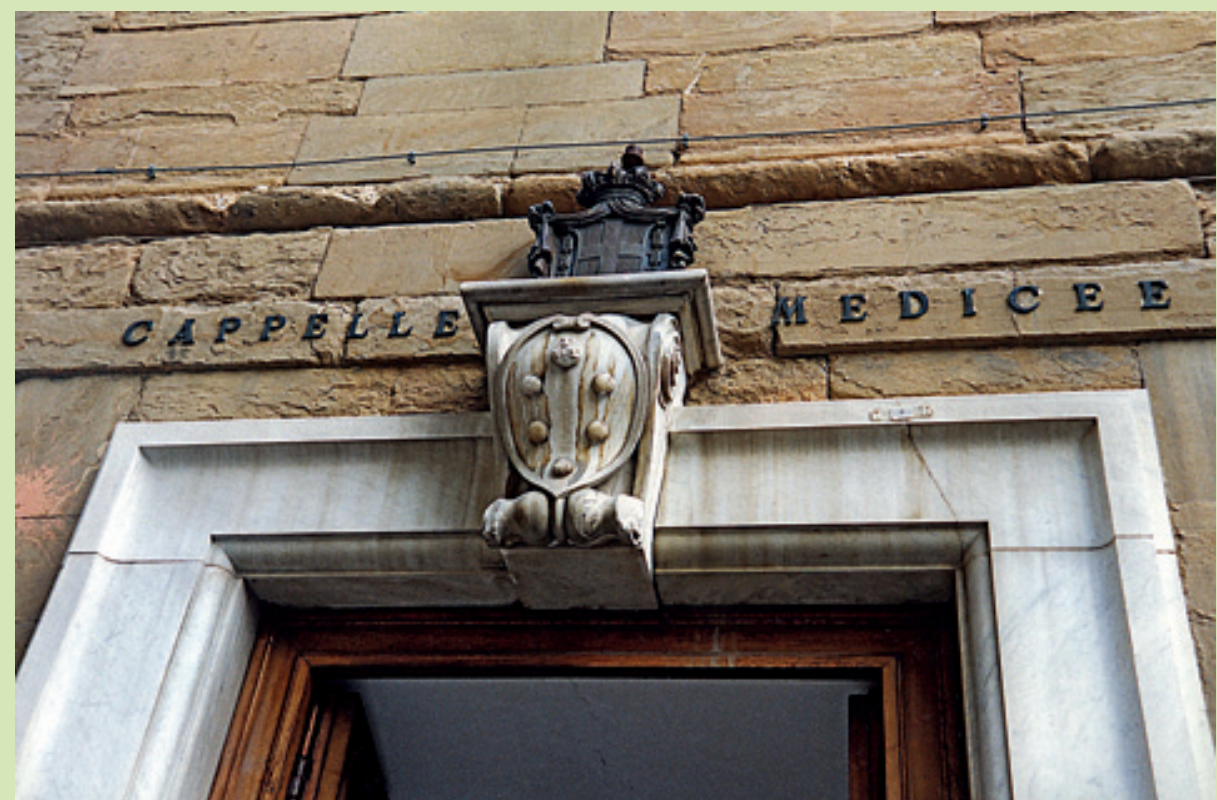

Figur 2 Våpenskjoldet til Medici-familien, fra Medici-kapellet i Firenze. De runde ballene er sannsynligvis piller som avspeiler familiens bakgrunn som leger og apotekere (før de ble valutameglere, bankmenn og senere kustmesener og herskere i Toscana) Tre ble paver og to ble franske dronninger selv om det er ulike teorier om våpenskjoldets tolking

den europeiske medisinske iglen, Hirudo medicinalis, er den viktige) ble mye brukt i middelalderen, smeltet ordet lege sammen med ordet for det blodsugende dyret med antikoagulerende og lokalt smertestillende effekt $i$ engelsk (4-6). Man vet at igle het lyce $\mathrm{i}$ det 10 . århundre, senere laece. $\mathrm{Og}$ så ble det altså det samme ordet som middelalderengelsk for lege: begge ble til leech. Leech for lege er nå foreldet. På gammelnorsk har vi læknir, på færøyisk læknir, på dansk læge, på svensk läkare. Andre avledninger av roten er lektor, lex (samling av regler), lege artis (oversatt av Ernst SchjøttRivers til: «etter alle Knutsens regler») logisk, logos, -logi (4-6).

Physician kommer av én av de mest grunnleggende rotter i protoindoeuropeisk (4): bheu: å bo, å vokse - det bruktes om naturen selv. Phusis var runnen av denne rot i gresk: natur, fysikk og fysiske ting - på vei til det moderne ordet fysikk. En physician (engelsk) studerte først naturlige ting. Før 1200 var betegnelsen fisician; som altså ikke bare gjaldt gastroenterologer (4-6). At f ble skiftet ut med ph kan kanskje avspeile fransk-normannisk påvirkning? Andre avledninger: phylon, gresk for: stamme (som bor sammen) - videre fylogeni, fylo-

\section{Ramme 1}

Lines on the antiquity of microbes

Adam

Had 'em

Strickland Gillilan (1869-1954) skrev

i 1904 disse linjene som lenge har vært

regnet som verdens korteste dikt genetisk, fysiologi, symfyse, stadsfysikus. Jeg så nylig en flaske mineralvann i Hellas med to etiketter. Den engelske hadde teksten Natural water, den greske Fysiko nero (fig 1) (4-6). Nero har rot med betydning fersk. Ordet brukes om fisk og vann (4).

Doktor: Av den protoindoeuropeiske roten dek: å ta, akseptere, og å være noe ordentlig, akseptabelt; nyttig. Dette ble til docere i latin: å lære bort: å få til å akseptere. Andre avledninger av roten er: dosent og dogme (4-6).

Med: $\AA$ ta passende mål; gammelgermansk metan. Avledninger: medisin, remedie, meditere, modest, modal, modene, Medici (fig 2) (4-6).

$\AA$ være en ordentlig god lege er meget krevende faglig og menneskelig i vår tid da man faktisk med oppsamlet kunnskap, bedre utstyr og medisiner kan utrette mye mer for pasientene enn for få tiår siden (8). Til sammen definerer de nevnte språklige betegnelsene for lege og fag selv $i$ dag meget godt hva som trengs for å være en dyktig lege.

\section{Litt biologi på slutten}

Den protoindoeuropeiske roten pneu er å puste; en nasalisert form av pleu som betyr kraftig utpust. Fra gresk kom pneuma: den vitale ånd. Av dette fulgte pneumoni, apné, dyspné - og pneumokokk (4-6, 12-14). Pneumokokker har man også funnet hos sjimpanser, og Kilian og medarbeidere har holdepunkter for at pneumokokkene har sitt utgangspunkt $i$ våre prehominide forfedre fra for rundt sju millioner år siden (12) (ramme 1). Det er også interessant at statistiske, objektive metoder som brukes til å se på slektskapet mellom biolo- giske arter (12-15), nå også med hell er brukt til å studere slektskapet mellom språk og til å konstruere språkdendrogrammer (5). Q.s.

\section{E. Arne Høiby \\ arne.hoiby@fhi.no \\ Folkehelseinstituttet \\ Postboks 4404 Nydalen \\ 0403 Oslo}

Oppgitte interessekonflikter: Ingen

\section{Litteratur}

1. Oppenheimer S. Out of Eden. London: Robinson, 2004

2. Bryson B. A short history of nearly everything. New York: Broadway Books, 2005

Ross PE. Hard words. Sci Am 1991; 264, nr. 4: 71-9.

4. Watkins C. Indo-European roots. Boston: Houghton Mifflin, 2000

5. Clackson J. Indo-European linguistics. Cambridge: Cambridge University Press, 2007.

6. Barnhart RK, Steinmetz S, red. Chambers diction ary of etymology. New York: Larousse Kingfisher Chambers, 2003

7. Webster's new twentieth century dictionary of the English language unabridged. 2. utg. Cleveland: The World Publishing Company, 1972.

8. Thomas $L$. The youngest science. Notes of a medicine watcher. New York: Viking Press, 1983.

9. Heyerdahl GH. Legenden Carl Marstrander Språknytt 1992, nr. 2: 8-10. www.sprakrad.no/ nbno/Toppmeny/Publikasjoner/Spraaknytt/ Arkivet/Eldre/Legenden_Carl_Marstrander/ (27.8.2009).

10. Bjorvand H, Lindeman FO. Våre arveord: etymologisk ordbok. 2. utg. Oslo: Novus, 2007.

11. Mitchison J, Lloyd J. The book of animal ignorance. London: Faber and Faber, 2007.

12. Kilian M, Poulsen K, Blomqvist T et al. Evolution of Streptococcus pneumoniae and its close commensal relatives. PloS ONE 2008; 3: e2683.

13. Sogstad MK, Høiby EA, Caugant DA. Molecular characterization of non-penicillin-susceptible Streptococcus pneumoniae in Norway. J Clin Microbiol 2006; 44: 3225-30.

14. Vestrheim D, Høiby EA, Aaberge IS et al. Phenotypic and genotypic characterization of Sreptococcus pneumoniae strains colonizing children attending day-care centers in Norway. J Clin Microbiol 2008; 46: 2508-18.

15. Cavalli-Sforza L, Feldman MW. The application of molecular genetic approaches to the study of human evolution. Nat Genet 2003; 33: 266-75.

Manuskriptet ble mottatt 27.8. 2009 og godkjent 12.11. 2009. Medisinsk redaktør Raida Ødegaard. 